\title{
Analysis and Research on College English talents training mode from the perspective of contemporary new media
}

\author{
Huang Yafen \\ Nanchang Institute of Science \& Technology, Nanchang 330108, China
}

Key words: new media; English talents; training mode;

\begin{abstract}
With the continuous development of information technology and science and technology, new media has been widely used in all areas of our lives, it makes our life more convenient. With the social and economic requirements for English Majors in Colleges and universities of our country continues to improve, the traditional English talents training mode has been unable to meet the requirements of the new era, this paper mainly analyzes the present situation of College English talents training mode, and combined with new media technology and puts forward some new training mode, the purpose is to improve the comprehensive quality of English talents and to meet the demand of society for English talents.
\end{abstract}

\section{Introduction}

With the continuous exploration and renewal of educational system and educational model, the educational system of our country has been continuously improved. In this context, the modern educational means have been widely used in higher education, especially the new media technology. The new media technology has been widely used in the teaching of College English because of its interactive, digital and effective features. College English belongs to the application and practice of the subject, the subject content more widely, if still using the traditional teaching mode of the cultivation of English talents, so can improve the overall quality of English talents, which requires the use of new media technology, providing high-quality learning resources and broad learning platform for students, and promote the comprehensive development of English majors.

\section{The main features of the new media}

The traditional media including radio, television, newspapers, magazines, and new media is mainly based on Internet technology, micro-blog, WeChat, QQ, intelligent mobile phone, computer, mobile TV and other ways to use new media forms of dissemination of information to the people. Compared with the traditional media, the new media has the following characteristics:

(1) Abundance of resources. With the continuous updating of mathematics, mobile communication, new media technology and network technology, a huge network system has been formed. Users can access a large number of high-quality resources through different channels, especially with the integration of mobile phones, computers, digital TV, users can search and find the information they need anytime, anywhere.

(2) Interactivity. Interactivity is the essential characteristic of new media. The new media has built a mutual exchange and communication platform for the users by using WeChat, micro-blog, QQ, renren.com, Post Bar means, network users can not only receive information and release information through the network, but also without geographical restrictions and time limits to interact. 
(3) Individualization. New media can make every user become a publisher of information, users can not only express their views and opinions on the new media platform, can also according to their own interests personalized settings, choose a personalized form of communication. Especially in the contemporary society, users are constantly pursuing personalized, new media constantly update and broaden the personalized applications and services, making the new media users increasingly.

\section{The present situation of College English talents training mode}

The cultivation of English talents in Colleges and universities needs to be improved. In recent years, with the accelerating pace of social development, the rapid development of society has also put forward new requirements for the training mode of College English talents. At present, China's social economy has been fully improved, in various fields and between the world will continue to become more frequent, the English majors are facing more and more challenges, but also to provide them with a broader development platform and brighter prospects. However, now English talents in Chinese colleges and universities training mode is still relatively backward, it only pay attention to teaching basic knowledge, and not used to be able to put the students into both professional and cultural knowledge, and understand the local culture, social and economic comprehensive knowledge of the application type, with type of professional talent training mode.

Curriculum design does not meet the practical needs. At present, we still use the traditional teaching content in the course of English Majors in Colleges and universities. This traditional method of setting up the curriculum, easy to lead to teaching and practice can not be effectively combined with the situation, so that students lack the opportunity to practice. The cultivation of English Majors in Colleges and universities can not keep up with the speed of national economic development, and also the lack of understanding of social formation, and in the process of training English talents, we neglect the comprehensive knowledge of natural science and humanities, so that the English talents can not meet the needs of modern society and economic development. At the same time, in the process of the cultivation of English talents in Colleges and universities, there are also some problems in the curriculum and professional setting and practice, which is not enough to be specialized and outstanding.

Teachers are not strong. According to the actual situation of teachers in one university, the situation shown in the following table:

Tab.1 Statistics of College Teachers

\begin{tabular}{|c|c|c|c|}
\hline Year & Number of Teachers & Number of Students & The ratio \\
\hline 2009 & 22 & 3500 & $1: 159$ \\
\hline 2010 & 21 & 3624 & $1: 162$ \\
\hline 2011 & 23 & 4025 & $1: 166$ \\
\hline 2012 & 23 & 4800 & $1: 170$ \\
\hline
\end{tabular}

From Table 1, we can directly find the serious shortage of College English teachers, especially after the expansion of enrollment in Colleges and universities, the number of students has risen sharply, but the number of English teachers in Colleges and universities has not changed significantly. This leads to a lot of teachers' teaching tasks, teaching hours too much, not enough time and energy to improve their comprehensive strength and comprehensive quality, which would undoubtedly mean "draining the pond to get all the fish". 


\section{The influence of new media on College English talents training mode}

Create a new teaching model using new media. With the development of science and technology, intelligent mobile phone, iPad, notebook computer as the most popular, the most widely spread of new media, with its efficient, convenient, intelligent features such as people get unanimous approval. For the widespread use of the campus network of colleges and universities, the proportion of students using WiFi Internet reached $100 \%$. It can be found that the popularity of the Internet has laid an important foundation for the use of "new media" to impart knowledge, the ability of college students to accept new things quickly provides guarantee for the use of "new media" to impart knowledge. The application of "new media" to the construction of a new college English teaching model mainly includes the following three parts: First, the learning community, that is, the class as a unit, composed of teachers and students together to learn community; two is the guide, mainly refers to teachers. Three is the exchange platform, teaching activities can not be separated from the exchange and discussion of the problem. On the basis of these important components, this paper establishes a college English teaching model based on "new media":

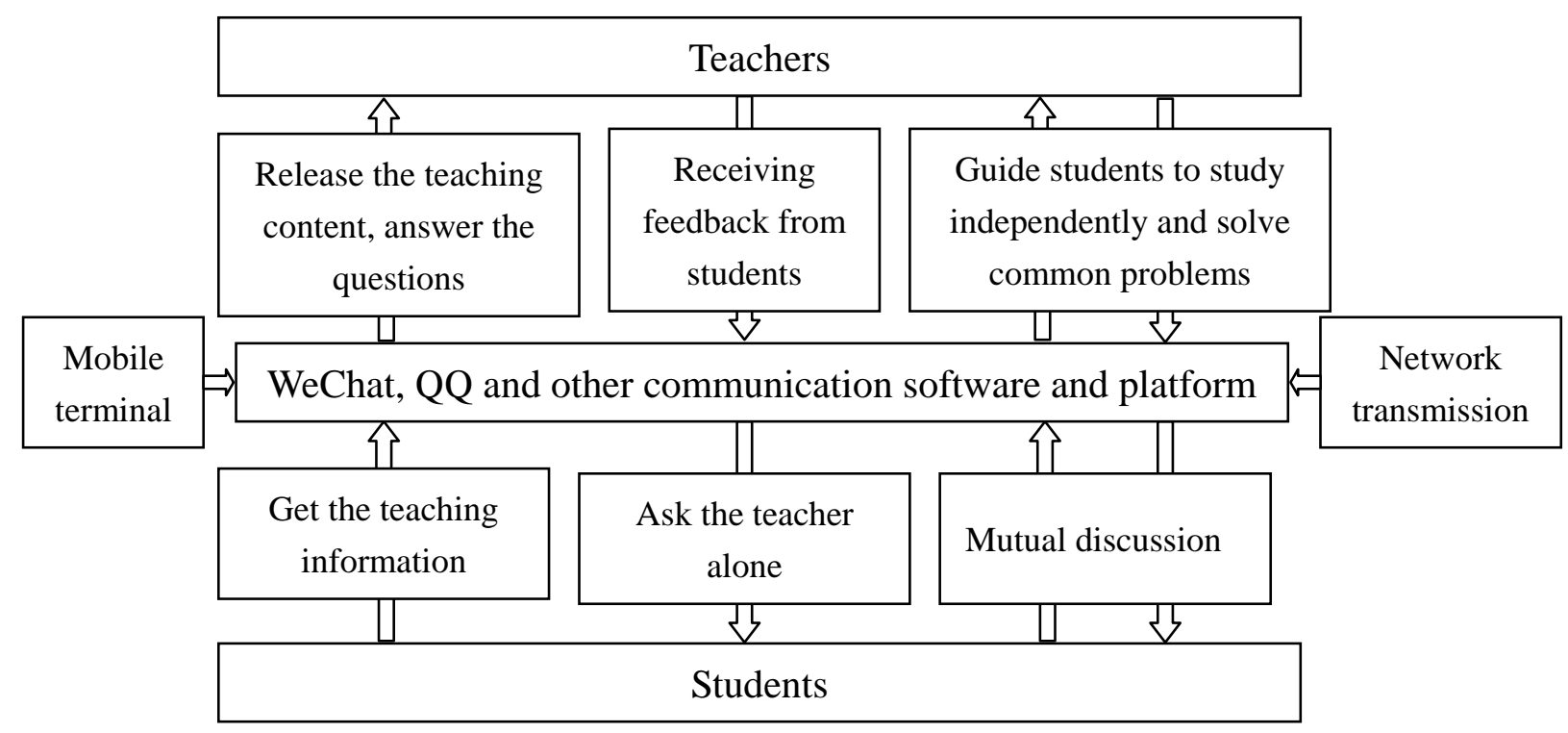

Fig. 1 College English teaching mode based on "new media"

Strengthen the use of new media, improve students' English listening ability. In the process of English Teaching in Colleges and universities, it is possible to create better classroom atmosphere and improve interest in English class by setting up the classroom situation. For example, a university teacher in training students' listening ability, she does not have a traditional teaching mode in accordance with the method, but the use of television teaching, let students watch some to reflect the foreign cultural customs, living habits, historical background of classic movies. This will not only enable students to understand the use of English in the spoken language, but also to train the students' listening ability, making the boring English class become lively and interesting. In addition, teachers can strengthen the use and sharing of new media resources in English class, so that students can learn independently. In the training of listening ability for English majors, we should integrate new media resources and all kinds of teaching materials in time, so as to provide more material for students. For example, teachers can use some software to make courseware with graphics, animation, sound, so that students can also use the electronic listening courseware in the practice outside the classroom, so continuously improve their English listening ability.

Strengthening the ability of College English teachers to use new media. At present, many college English teachers do not have a good grasp of information technology and resources, 
resulting in the use of information technology and resources in English class is low, there is no effective play the role of new media. Therefore, it is an important part of College English teaching reform to strengthen the training of College English teachers' comprehensive ability and quality. First of all, teachers' awareness of information should be cultivated, for example, in the process of teaching knowledge, college English teachers must constantly learning, constantly improve their comprehensive application ability, but also to improve their mastery and application of new media equipment capacity, so as to realize the modernization and informatization of College English classroom. In addition, teachers should use the new media platform to communicate with students in the process of English teaching. Students can not only learn English in the classroom learning, but also can be extended to after-school and life, so that students in their daily lives can also communicate with the teacher and learning in a timely manner. For example, teachers can set up a WeChat group or QQ group, to enable students to communicate in English in the group, this model can not only train the students' listening ability, can also exercise the students ability of oral English expression. Teachers can also use the network chat, network distance education and other ways, anytime, anywhere to answer the students confused, so as to improve students' English proficiency.

\section{Conclusion}

With the development of digital information technology, the promotion of the triple play strategy advocated by the state, the new media industry has been rapid development, greatly increasing the market demand for talent, but it also puts forward higher requirements for the cultivation of English majors, and the reform of the training mode of English majors has become more and more intense under the new media. As a new type of information carrier, "new media" can transmit information through the mobile terminal, which can facilitate the interaction and communication between students and teachers. At the same time, the new media have created a relaxed and interesting learning environment for students, to stimulate students' autonomous learning ability, combined with new media technology in College English classroom to cultivate English talents, to achieve all-round development of English majors.

\section{Reference}

[1] Ma Lina. Under the perspective of economics of language in English on the innovation talents training model [J]. Journal of Higher Education, Vol.13, (2016) , p.1-2,5.

[2] Liang Jing. From the perspective of cross culture study of College English teaching model [J]. China Market, Vol.23, (2016) , p.208-209.

[3] Wang Qun, Weng Xuefang. University English professional training status and training mode of [J]. science and technology economy, No.09, (2015) , p.235

[4] Luo Zhiyong. Study on the training model of English Majors in Independent College [D]. Tianjin University, (2015)

[5] Shen Yanmin. Innovation of College English talents cultivation in the perspective of new media [J]. Chinese \& Foreign Entrepreneurs, No.05, (2015), p.181

[6] Ye Guancen. Analysis of the demand of logistics English market and the training of logistics English talents [J]. Chinese \& Foreign Entrepreneurs, No.03, (2015) , p.35 
[7] Sun Shumin. How to develop students' autonomous learning ability in senior high school English Teaching under the new curriculum reform [J]. Learning Weekly, Vol.28, (2014) , p.145

[8] Zhou Fengqin. Problems and Countermeasures of current college English talents training mode [J]. Education and Vocation, Vol. 18, (2014) , p.117-118.

[9] Song Linshan. Reform and Research on the training mode of College English Majors [J]. English Square, No.08, (2012), p.99-101.

[10] Bai Xue. The study of curriculum design of English Majors in Local Normal Universities from the perspective of compound talents [D]. GanNan Normal University, (2012)

[11] Bai Xue, Zhu Xiaodong. Study on the curriculum setting and compound talents of English Majors in local teachers colleges and Universities: a case study of GanNan Normal University [J]. Education for Chinese After-school(Theory), Vol.15, (2012) , p. 106,89

[12] Li Nan. The study of English and Chinese culture in College English teaching from the perspective of intercultural communication [D]. Jilin University, (2012)

[13] Huang Yi. On the training mode of professional interpreting talents in English and its teaching model [J]. Journal of Guangdong University of Foreign Studies, No.05, (2007), p.74-76. 